Article

\title{
Energy Demand of Short-Range Inland Ferry with Series Hybrid Propulsion Depending on the Navigation Strategy
}

\author{
Magdalena Kunicka $\mathbb{D}^{\mathbb{D}}$ and Wojciech Litwin * \\ Faculty of Ocean Engineering and Ship Technology, Gdansk University of Technology, ul. Narutowicza 11/12, \\ 80-233 Gdańsk, Poland; magdalena.kunicka@pg.edu.pl \\ * Correspondence: wojciech.litwin@pg.edu.pl
}

Received: 6 July 2019; Accepted: 8 September 2019; Published: 11 September 2019

check for updates

\begin{abstract}
Interest in hybrid propulsion systems that can be used on small vessels has increased significantly in recent years. They can replace inefficient and environmentally burdensome conventional systems based on diesel engines. Hybrid propulsion has many advantages such as high energy efficiency and virtually noiseless operation, and therefore it fits well with the current trends of "green shipping" and "zero emission". The aim of the research conducted was to examine and analyse the varied energy demand of a small inland ferry with electric propulsion depending on the navigation strategy. The work included tests carried out on a model of the vessel. Conventional resistance tests involving towing the model at a constant speed proved to be of no use for the unit, which, during a short voyage, moves with variable speeds and manoeuvres. Therefore, atypical and unique tests were performed to determine the energy consumption during the acceleration of the unit and the parameters of navigation with the propulsion turned off. The work resulted in calculated forecasts of energy consumption by the ship depending on the adopted cruising style and a proposal of the most energy-efficient way to cross the shipping route connecting the two banks of the Motława River in the city of Gdańsk.
\end{abstract}

Keywords: hybrid ship propulsion; hybrid propulsion; energy management; green shipping; energy consumption; energy efficiency

\section{Introduction}

After centuries in which sailing propulsion dominated, the first mechanical propulsion of ships was implemented in the nineteenth century. While work on steam engines was still carried out, electric propulsion was probably applied to a vessel for the first time by H. H. Jacobi in 1834 [1]. Initially, this solution was ignored due to the serious limitations of such a propulsion system, resulting from the imperfections of the electrical machines of the time and the lack of an effective power source, among others. The situation changed when further inventions were improved and implemented. At the end of the nineteenth century, it was possible to construct acid and alkaline batteries. Electric motors and generators were also improved. As can be easily guessed, all these solutions were first implemented for the needs of the military, that is, the navy. After several decades of work carried out by various inventors, John Holland launched the first fully functional and relatively safe submarine with a hybrid parallel-combustion electric drive in 1896. To this day, this type of drive, called diesel electric propulsion, is used for submarines. The significance of this invention was fully understood during the First World War, when the submarines paralysed shipping routes and sank ships, with a total tonnage of about 11 million tons.

Over the years, electric propulsion was refined and other major obstacles to the development of electric propulsion on vessels were gradually overcome [1]. After the Second World War, electric 
propulsion was successfully used on special ships, such as icebreakers and passenger ships. This resulted from the advantages of such propulsion, including, among others, the possibility of a quick change in the rotational speed of the propulsion shaft (icebreakers) or the lack of vibrations of the hull typical of large diesel engines, which had an impact on the comfort of cruising, especially on passenger ships. It was not until the end of the twentieth century that efficient and reliable frequency converters (AC converters) and high-torque electric motors with permanent magnets were implemented. At the beginning of the twenty-first century, thanks to the development of portable electronic devices such as laptops and mobile phones, it was possible to develop the production of light and energy-efficient lithium batteries. More and more often, the classic propulsion system with the shaft line was abandoned and electric motors were assembled inside gondolas suspended under the hull of a ship, called the azimuth thruster. The engine room, which was the source of energy, was often dispersed by installing several smaller power generators [2].

In 2013, the world's first hybrid ship equipped with a $500 \mathrm{kWh}$ battery system, MV Viking Lady, was launched. From that moment, more hybrid ships were designed and built. In the same year the new offshore supply ship MV Edda Ferd was constructed [3]. Then, in 2015, the MV AMPERE shuttle ferry, probably the world's first large watercraft with its propulsion provided exclusively by batteries, was built, [2,3]. The decision to build this very expensive unit was based on several reasons, for example, the idea of building a ship with virtually zero exhaust emissions. Today, when more and more importance is attached to environmental protection, advanced technologies related to electric and hybrid propulsion are becoming more and more popular [4-10]. Upon analysing various criteria, such as limiting emissions of harmful compounds, energy or fuel consumption, the volume and mass of the ship's engine room, the manoeuvrability of the unit, and the operating costs, the use of hybrid propulsion becomes more and more often justified [11].

\section{The Problem}

Presently, as electric drives are more and more commonly used for the propulsion of vessels, the safety of navigation is of great importance [12-15]. The classification societies control ship designs, accept and certify specific products for use in shipbuilding, and keep watch over the technical conditions during ship operation. On large ships, when comprehensive solutions produced by global corporations are used, a high level of safety is usually maintained. The situation is different for smaller units. Designers design the propulsion and power system by combining components from different suppliers. This creates a whole range of problems at the level of integration of the propulsion and power system. Proper energy management, which is especially important when the propulsion system is powered by batteries that have a certain capacity, is another problem [16-18]. The price of the batteries is high, so designers try to limit their number while reducing their weight at the same time. Classification societies allowing vessels to be used in such a case usually require that a power generator be installed on the unit as a standby power source. This is a similar solution to that used in some electric cars manufactured by renowned firms, when an optional power generator is installed on request. The significance of the problem is confirmed by cases of power outages resulting from the discharging of batteries during the voyage on some inland vessels. In cases known to the authors, no catastrophe occurred, as the ship was anchored. However, the vessel had to wait for help from a tugboat and the passengers and crew waited for help from outside.

The answer to the question of why similar situations occurred in the past is not simple. Quickly, but often all too soon, it can be concluded that the battery capacity is insufficient. However, it should be remembered that a large mass of batteries incurs not only a huge cost but also results in a large draught of the ship and consequently significant resistance to cruising and, thus, increased energy consumption. From practical experience, it is clear that the style of operating a ship has a key impact on its energy consumption. In a Polish city in 2004, when a communication line based on small vessels with electric propulsion was implemented, the crew discharged the batteries after the first two hours of the cruise. Only the training of the crew, and especially the elimination of control habits arising 
from many years of work on ships with conventional diesel drives, allowed the water tram to run for a full eight hours.

While carrying out further work on electric and hybrid propulsion [19-22] on the occasion of a small inland shuttle ferry project for the city of Gdańsk (Figure 1), the designers paid particular attention to the problem of energy management [23-26].

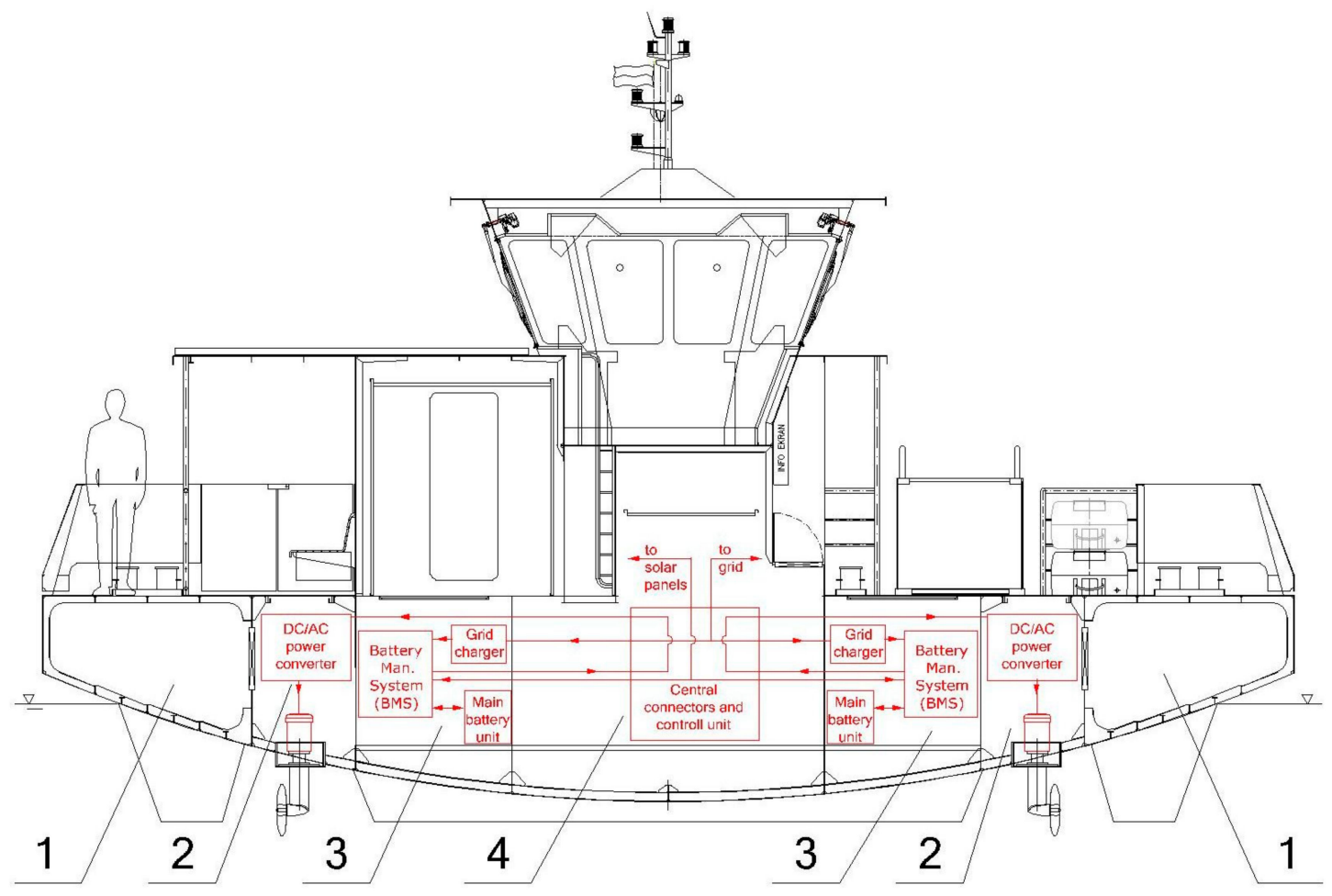

Figure 1. Propulsion and power supply system schematic of the Motława II Ferry; 1 -collision bulkhead; 2-propulsion compartment, 3-battery compartment, 4-crew room with main switchboard.

It turned out that the classic methods of calculating the demand for propulsion power $[27,28]$ are practically useless. In typical cases, like sea-going journeys, when it is necessary to determine the necessary propulsion power to obtain a specific speed, resistance calculations or model tests in a test laboratory are performed by towing a scale model. These techniques are the basis for calculating the propulsion power and they allow the energy consumption during the voyage to be estimated. In the case of sea-going ships, their movement is similar. In the model tests of these units, mainly the energy consumed while moving at a constant speed on the open sea is taken into account. Different energy consumption is not taken into account due to, e.g., manoeuvres, because in this case they are small compared to the entire demand.

The case subjected to analysis is different. The ferry covers a route with a length of about $100 \mathrm{~m}$. For a significant part of the cruise duration, the ship accelerates or brakes, which is why the resistance and power requirements determined in the classic way become useless. For the purposes of the project, the daily energy consumption was estimated, because it was assumed that the shuttle service cannot recharge its batteries during a few minutes' break between routes. To ensure high durability of the batteries, they were expected to be charged during a night standstill. However, in order to study the nature of the problem of energy consumption, propose an effective energy management strategy, and, at the same time, to provide a certain ability to perform the assumed number of courses, the experimental studies and calculations described below were performed. 


\section{Energy Management Strategy}

The key problem in minimizing energy consumption by the ferry is to propose a strategy according to which the ferry can move between two river banks. It is important that in the peak tourist season, when the frequency of cruises is the largest, the assumed number of courses is completed rationally, managing the energy accumulated in the batteries on board. It is worth noting that where the Motława River flows through the historic and attractive part of the city of Gdańsk, it is a crowded water area and sometimes the helmsman must correct the course to avoid other vessels. These events occur by accident but, while determining a power demand, it is worth taking into account the additional capacity of the batteries.

Prior to the start of the research on the cruising strategy, a speed profile of the currently operating ferry, which is equipped with conventional propulsion and was built 30 years ago, was obtained. The results of the measurements showed that the unit covers the route at a constant low speed of approximately 4 to $5 \mathrm{~km} / \mathrm{h}$ (Figure 2). The duration of the voyage can be divided into four consecutive stages, as follows: Acceleration, flow with constant speed, a short stage when the drive is not working and reverse gear is engaged, and the braking phase is activated. The classic cruising strategy is called ACB (acceleration, cruising speed, braking).

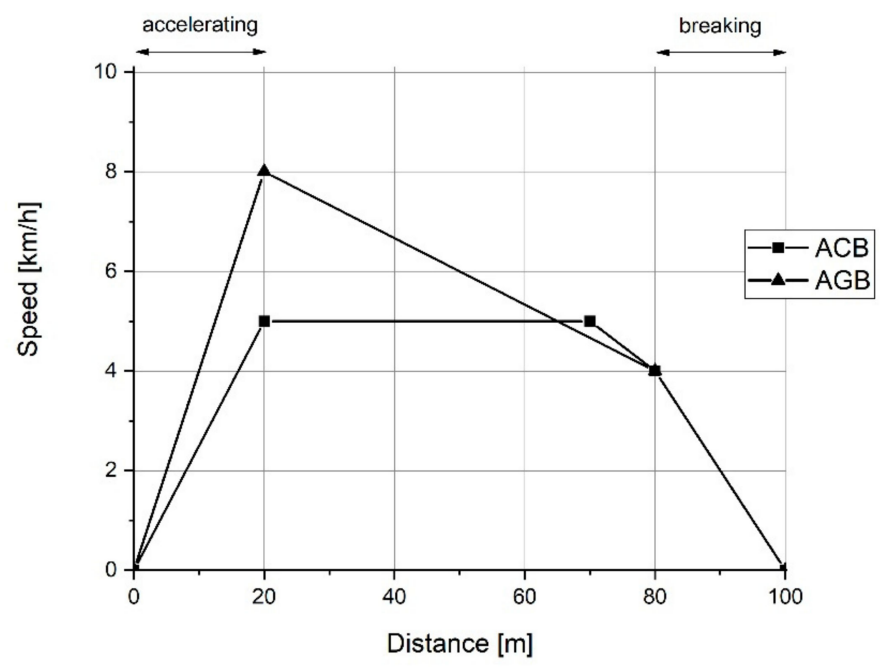

Figure 2. Ferry speed profiles for the two analysed traffic strategies: ACB and AGB.

Using previous experience, it was decided to examine the different cruising strategies shown in the graph below (Figure 2). It is based on accelerating the ferry to speeds of about 8 to $10 \mathrm{~km} / \mathrm{h}$, higher than those usually achieved, and then free movement by coasting, called gliding, with the engine turned off, ending with the braking phase. The proposed strategy is called AGB (acceleration, gliding (coasting), braking).

According to the adopted assumptions, in order to achieve the desired transport objective in the summer season, that is, covering the entire round trip route every $6 \mathrm{~min}$, it was assumed that the one-way (half way) cruising time should be no more than $90 \mathrm{~s}$, without a time to get in or out on board. The measurements carried out on the currently operating unit show that the time required to allow passengers to disembark and new ones to board is usually about $3 \mathrm{~min}$.

In order to perform an accurate analysis of the energy demand according to the proposed new AGB strategy and to compare the results with those of the classic ACB strategy, it was necessary to examine the energy demand during the acceleration of the ferry and the characteristics of gliding with the propulsion turned off. However, to determine these characteristics, typical studies of the power demand made in the model laboratory were insufficient. It became necessary to perform non-typical tests, which required the preparation of special equipment. 


\section{Tests}

The test was carried out in a towing tank using a 1:10 scale model of a ferry (Figure 3). The main dimensions of a real ferry are as follows: Hull length $-12 \mathrm{~m}$; breadth $-5 \mathrm{~m}$; total draught $-1,3 \mathrm{~m}$.

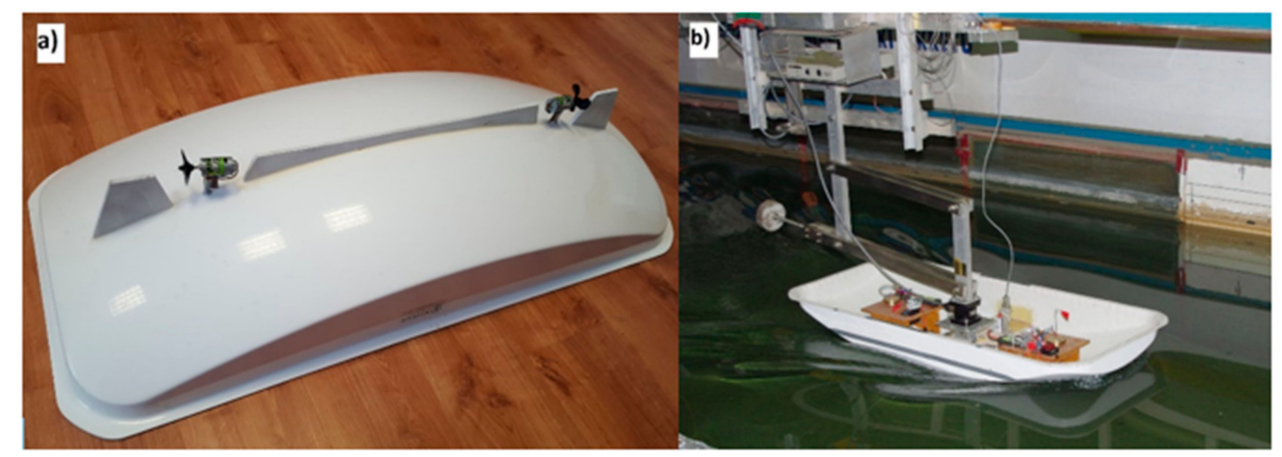

Figure 3. The 1:10 scale model ferry: (a) The final version with skegs and propulsion, allowing manoeuvring tests using remote control; (b) the model of the towing tank during tests, with a (rescaled for a real ferry) speed of $10 \mathrm{~km} / \mathrm{h}$.

The research began by performing classic towing power measurements in a towing tank when the model moved at constant speed. The total resistance of the ship was calculated by rescaling the results of the model resistance (Figure 4a). All resistance tests were performed on the model and then, according to three laws of similarity (geometric, kinematic, and dynamic), the decision was made to use the Froude criterion (which is based directly on the number of Froude) to scale the results [29-31]. To calculate the energy demand of the propulsion system, it was necessary to take into account the energy efficiency of this system. The decision was made to use AC motors with permanent magnets. The motor is controlled by a frequency converter powered by a lithium battery set. During previous research, the energy efficiency of a similar propulsion system was measured and it was found that the energy efficiency of such a power unit exceeds 90\% [20]. For further calculations, efficiency was assumed to be $\eta_{\text {mot }}=0.9$. It is known, however, that the main source of energy loss in the system is related to the propeller. Under fixed conditions, when the ship is moving at a constant speed, the efficiency of a properly selected or purpose designed propeller can reach 55\%. A slightly lower value, likely to be obtained on a small watercraft, was used for calculations, as follows: $\eta_{\text {prop }}=0.5$. Therefore, based on the classic model tests (towing tank tests), it was possible to determine the propulsion power demand when the ship was moving at a constant speed (Figure $4 \mathrm{~b}$ ). The obtained characteristic has a typical non-linear waveform showing how much the increase in cruising speed increases the energy needed to power the drive system.

a)

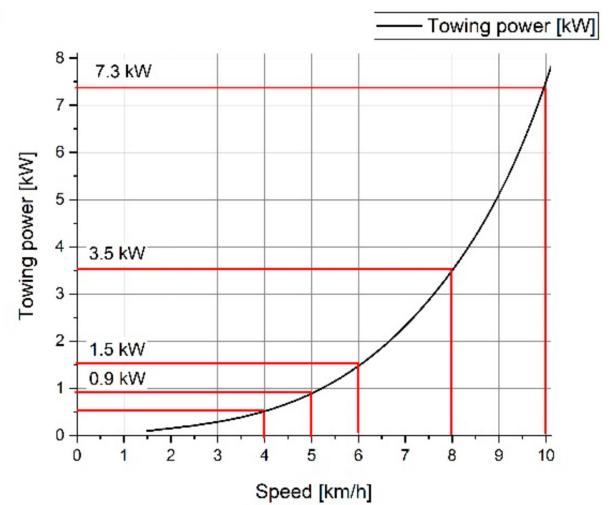

b)

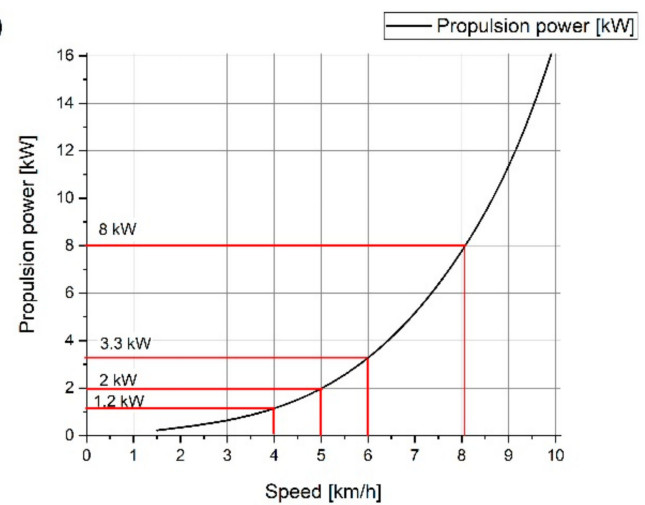

Figure 4. Graph of the power demand of the Motława II ferry as a function of speed: (a) Towing power graph, (b) power demand graph. 
The typical equipment of a complex test system such as a towing tank is usually not adapted to take measurements when the model is accelerated to a specific desired speed. Therefore, to determine the demand for energy during the acceleration of the ferry, three different characteristics of accelerating the model in the test laboratory were programmed. Thanks to this, it was possible to record the resistance force when accelerating the model to the predetermined speed. Knowing the speed of the model, the towing power was determined. However, it should be added that during acceleration and braking, the ship's screw works in unfavourable conditions and its efficiency is difficult to estimate. Therefore, for the calculation of the propulsion power and energy demand, the efficiency of the screw operation was assumed to be $35 \%$ during acceleration and $25 \%$ during braking, when the screw operates in particularly unfavourable conditions. The efficiency values were set on the basis of typical propeller efficiency curves from hydro mechanical characteristics [9,32-34].

Due to the limitations of the unit, which was not adapted to similar tests and was designed to tow the model at a constant speed, only three different characteristics were determined to accelerate the unit up to the assumed speed of $8 \mathrm{~km} / \mathrm{h}$, hereinafter referred to as processes $\mathrm{t} 1, \mathrm{t} 2$, and $\mathrm{t} 3$ (Figure 5 ). The acceleration process was carried out with three different accelerations so that the duration of the acceleration stage to the speed of $8 \mathrm{~km} / \mathrm{h}$ was $\mathrm{t} 1=12 \mathrm{~s}, \mathrm{t} 2=10 \mathrm{~s}$, and $\mathrm{t} 3=9 \mathrm{~s}$.

a)

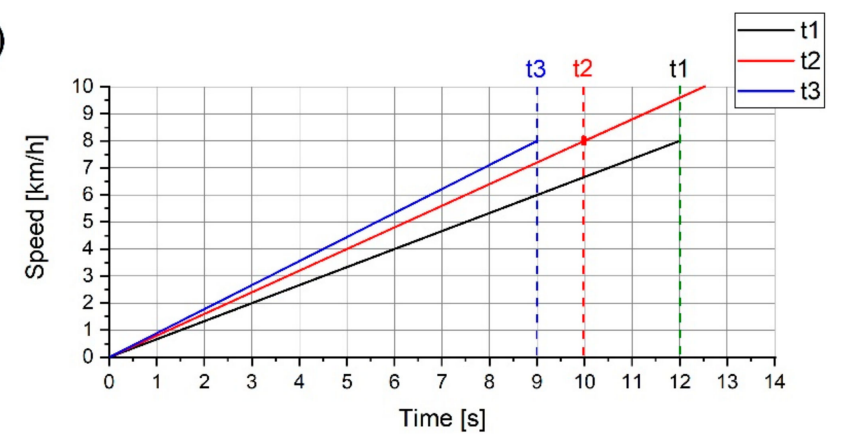

b)

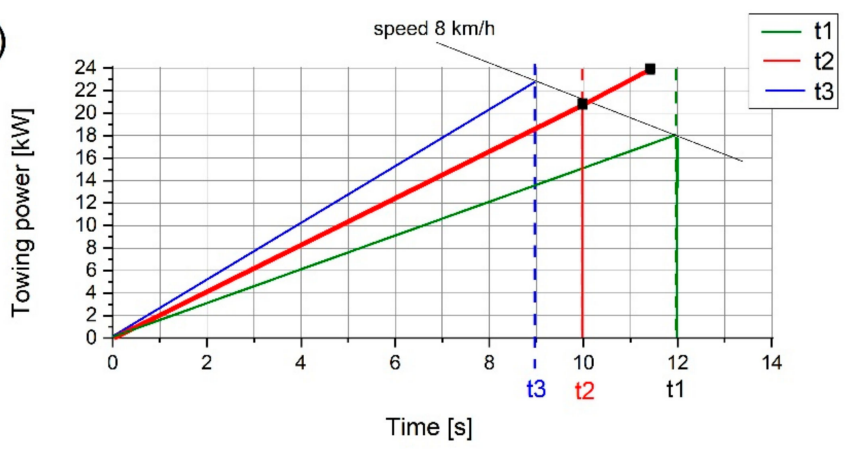

Figure 5. Measurement results in the model test laboratory during the acceleration of the model, showing acceleration variants from $\mathrm{t} 1$ to $\mathrm{t} 3$ : (a) The speed distribution of the ship and (b) the towing power of the ship.

To determine the demand for propulsive power and energy of the AGB strategy, it is necessary to examine the stage of gliding of the ship with the drive turned off. The authors of the study carried out research in a model test laboratory using a specially prepared measuring system, which allowed a model to move without any outside interference, making it possible to present the behaviour of the unit during the gliding stage. Free movement on the planned trajectory of a model shows a real reflection of gliding. The completed measurements allowed the preparation of vessel speed profiles and the calculation of the range (Figure 6).

The measurements show that the test vessel accelerating to $10 \mathrm{~km} / \mathrm{h}$ and then gliding freely after $29 \mathrm{~s}$ when its speed is $4 \mathrm{~km} / \mathrm{h}$ will cover a distance of $51 \mathrm{~m}$ (Figure 6). If we limit the speed of acceleration to $8 \mathrm{~km} / \mathrm{h}$, after $23 \mathrm{~s}$, the unit will cover a distance of $38 \mathrm{~m}$. On the currently operating ferry, 
$4 \mathrm{~km} / \mathrm{h}$ is the speed at which the drive braking usually begins. As can be seen from the characteristics, the process of decelerating the unit slows down and if the speed of the unit is accelerated to $10 \mathrm{~km} / \mathrm{h}$ and the gliding is finished when the speed drops to $3 \mathrm{~km} / \mathrm{h}$, after about $40 \mathrm{~s}$ the unit will cover a distance of about $62 \mathrm{~m}$.

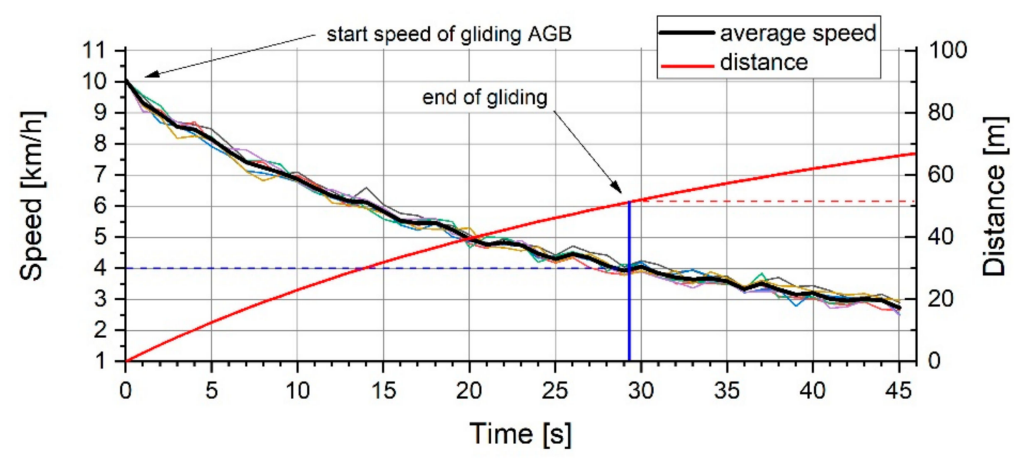

Figure 6. Graphs of instantaneous velocity and distance covered as a function of time for a ferry moving with the propulsion turned off, i.e., during gliding.

\section{Energy Demand Calculations}

The completed measurements made it possible to perform calculations and to determine the characteristics of instantaneous power demand and velocity as a function of time (Figures 7 and 8 ). For the analysis, measurements of the power needed to accelerate the unit were used when the speed of $8 \mathrm{~km} / \mathrm{h}$ was reached within $10 \mathrm{~s}$ (Figure 5, course t2). It was assumed that in each of the analysed cases, the cruise lasts $85 \mathrm{~s}$ and the route is $100 \mathrm{~m}$ long. It was assumed that the cruise runs smoothly, that is, the ferry does not have to avoid obstacles or perform sudden manoeuvres, for example, to avoid a collision.
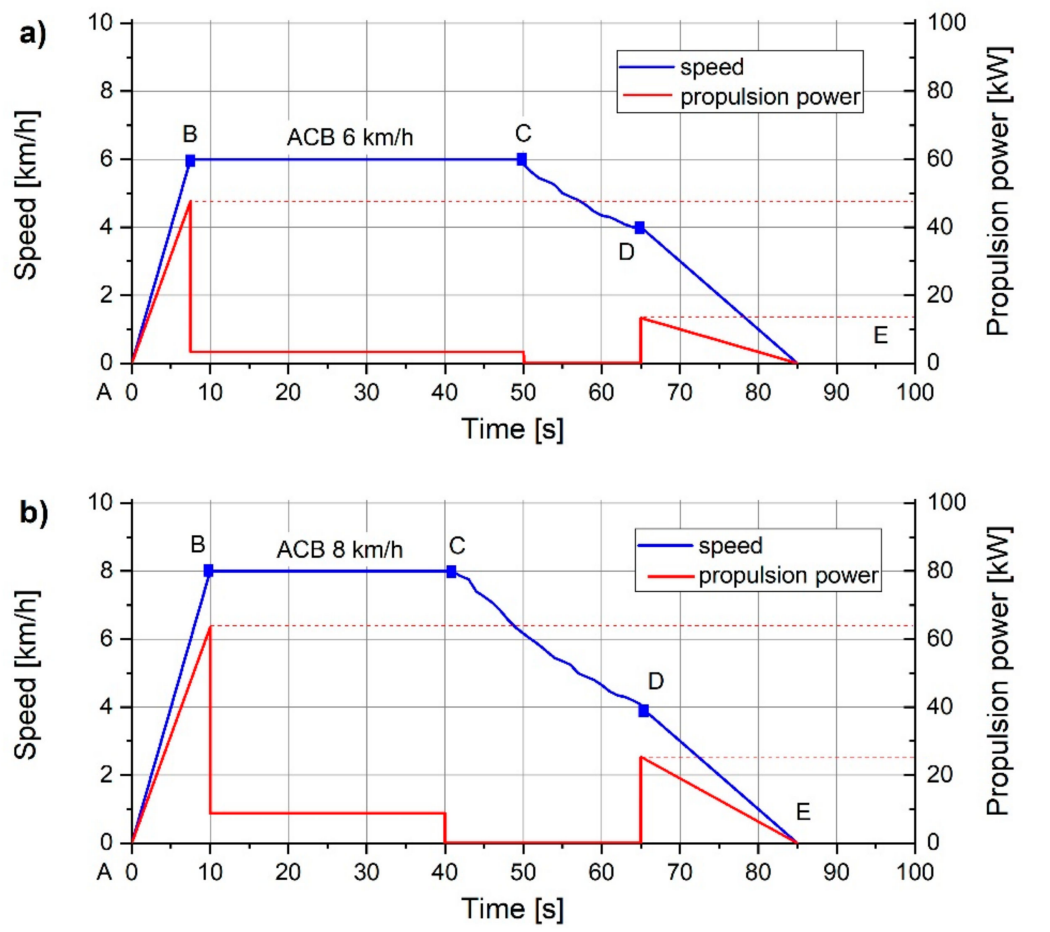

Figure 7. Ship speed and power demand for the ACB strategy: (a) Maximum speed of $6 \mathrm{~km} / \mathrm{h}$, (b) maximum speed of $8 \mathrm{~km} / \mathrm{h}$; A-start, B-end of the acceleration stage, C-propulsion turned off, D-start of braking, E-stopping of the vessel. 

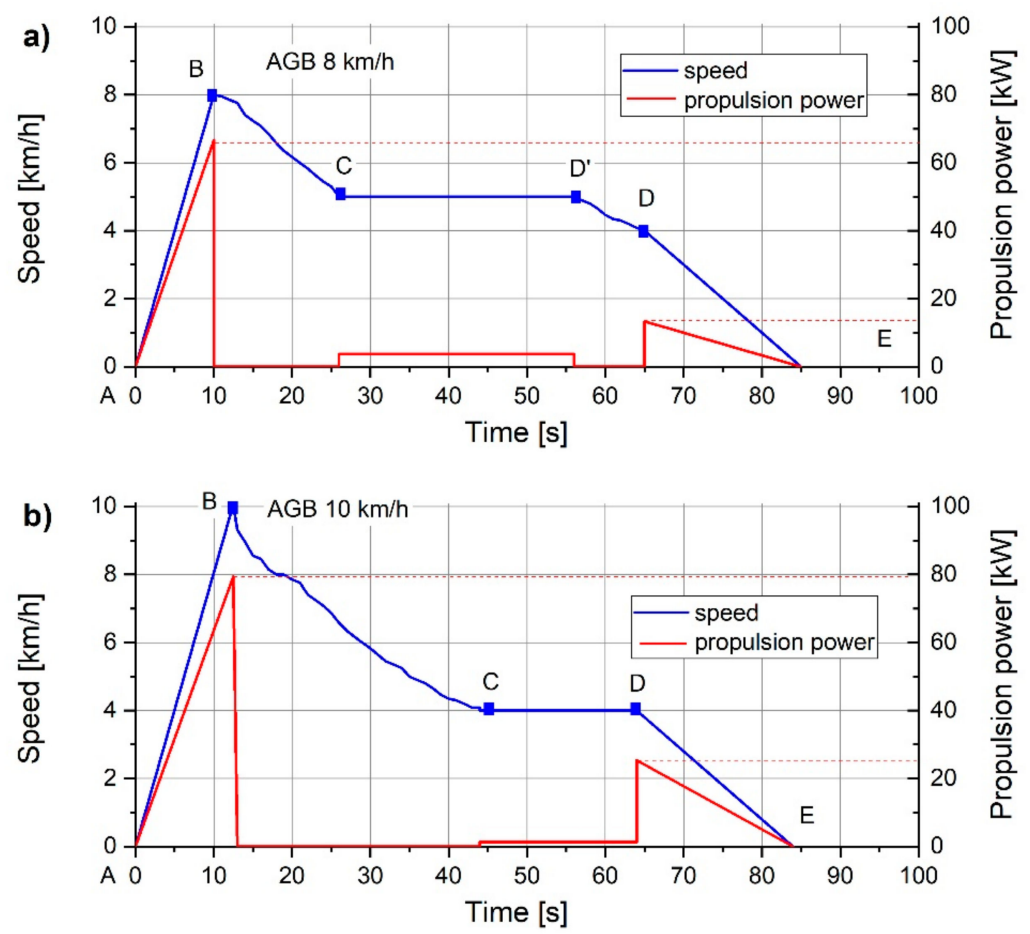

Figure 8. Ship speed and power demand for the AGB strategy: (a) Maximum speed of the acceleration stage of $8 \mathrm{~km} / \mathrm{h}$, (b) maximum speed of the acceleration stage of $10 \mathrm{~km} / \mathrm{h}$; A-start, B-end of acceleration and propulsion turned off, C-restarting of the propulsion, $\mathrm{D}^{\prime}$ - start of braking with gliding, with the propulsion turned off, D—start of braking with propulsion, E-stopping of the vessel.

The power demand characteristics marked on the charts were determined based on the experimental research described above. For the classic route-covering strategy (ACB, Figure 7), the results of measurements for the pre-defined state (Figure 4) and the acceleration stage were used (Figure 5). For the braking phase, it was assumed that the energy consumption was equal to half the energy needed to accelerate the ship. This is due to the fact that the ship's resistance naturally contributes to slowing down the ship's movement. The literature fails to provide the information on the efficiency of a propeller operating in the water while using the propeller to brake the ship. This problem will be explored soon using large-scale self-propelled models.

\section{Results and Discussion}

The ferry performs a maximum of 10 round trips per hour during the high season. This is due to the amount of time needed for boarding of passengers (1.5-2 min), cruising (less than $90 \mathrm{~s}$ ), and mooring of the unit and disembarking/embarking (1.5-2 min). Currently, it is planned that during the summer, when the amount of tourist traffic is greatest, the energy accumulated by the unit must be sufficient for $12 \mathrm{~h}$ of cruising, during which up to 120 return trips will be performed. The measurements made in the laboratory of the time needed to occupy space on the deck of a ferry using a specially prepared 1:1 scale model (Figure 9) showed that improving the process of boarding and leaving the ship is important for the number of courses that can take place within a specified time.

The obtained results make it possible to calculate the energy demand depending on the adopted cruising strategy. The calculations also included the time taken to complete the one-way course. Two cruising strategies, previously described by ACB and AGB, were analysed and two different maximum velocities of the vessel were adopted for each strategy. In order to compare the energy demands, it was assumed that a one-way cruise lasted $85 \mathrm{~s}$. As a result, the energy demand results obtained concern the same route and the same duration of cruising. 
The obtained results of energy consumption made on the basis of the previously presented graphs (Figures 7 and 8) for one hour of cruising, during which 10 round trips were performed, are presented in the table below (Table 1).

The values presented in Table 1 illustrate quite significant differences in the energy demand. The surprising conclusion is that the cruising strategy currently used (ACB) proved to be the optimal option for the assumed working conditions of the ferry. The calculations presented in Table 1 show that the theoretical minimum energy consumption in $12 \mathrm{~h}$ of intensive cruising is $12 \times 2.51 \mathrm{kWh}$, which is about $30 \mathrm{kWh}$. When designing the unit, it was assumed that there would be 44 standard lithium battery modules with a capacity of $2.5 \mathrm{kWh}$ to power electric buses with a total capacity of $110 \mathrm{kWh}$. The analysis shows that, after taking the energy supply at the level of 50\%into account, 18 modules with a total capacity of $45 \mathrm{kWh}$ are enough for a day-long, uninterrupted, and safe operation. The unit has spare space and buoyancy and, if necessary, the battery pack can be expanded.

The load on the power unit during acceleration to high speed when cruising according to the AGB strategy is another aspect worth considering. The drive with high power means that the propulsion, especially the motor, speed regulator, and gears, works with high efficiency. On the other hand, the high power brings considerable pressure forces, which are especially important for bearings and gears. Significant initial speed in the first stage of the cruise also leads to a higher risk of collision and, if necessary, sudden stoppage of the unit, with high energy consumption. It is worth noting that the first stage of the cruise is of special importance when the distance travelled by the unit is short. As the distance increases, the second stage gains importance as the energy consumption depends on the speed. In the cases discussed, the braking stage was always the same. It was assumed that the propulsion is activated to brake the vessel when the speed is $4 \mathrm{~km} / \mathrm{h}$. The adopted braking time of around $20 \mathrm{~s}$ allows the unit to stop slowly, which is comfortable for passengers and does not overload the propulsion system. Undoubtedly, an important share of the total energy consumption of a vessel during a single course results from the first stage of the cruise when the vessel is accelerating (Figure 5). The vessel then glides with the drive off (AGB) or moves at a constant speed (ACB). Therefore, an analysis of energy consumption in the initial stage of the trip was carried out. The course when the unit accelerates to the speed of $8 \mathrm{~km} / \mathrm{h}$ within $12 \mathrm{~s}$ was adopted as the base (Figure $5 \mathrm{a}$, course $\mathrm{t} 1$ ). Then, the vessel glides until the moment when its speed reaches $4 \mathrm{~km} / \mathrm{h}$. The cycle lasts $38 \mathrm{~s}$ and the vessel covers $52 \mathrm{~m}$. The following graphs (Figures 9 and 10) show the speed and power demand profiles of the two analysed navigation strategies, that is, AG and AC (the braking stage was omitted) for two different accelerations of the vessel ( $\mathrm{t} 1$ and $\mathrm{t} 3$ ). In order to be able to assess the impact of acceleration in the acceleration stage on energy consumption, it was assumed that, in each case, the ferry must cross the same route with a length of $52 \mathrm{~m}$. The assumed distance is the total length of the route during acceleration to the speed of $8 \mathrm{~km} / \mathrm{h}$ and gliding for variant $\mathrm{t} 1$ when the maximum speed is achieved within $12 \mathrm{~s}$ (Figure 5). In the present case, the duration of the trip is different and depends on the adopted strategy. Such a case is of particular importance when the cruise takes place without too much hurry and a difference of even a few dozen seconds is of no great significance. In the case of faster or slower acceleration under the AGB strategy, the time needed to cover $52 \mathrm{~m}$ was 38 to $39 \mathrm{~s}$. For the ACB strategy, it was 49 to $50 \mathrm{~s}$. The graphs below show the profile of the speed and power of the propulsion as a function of time for two different cases, $\mathrm{t} 1$ and $\mathrm{t} 3$ (Figures 9 and 10). The results of the calculations are presented in Table 2. The braking part in this comparison was omitted because, in every case, it was the same value and it did not affect the final result.

The results of calculating the energy demand in the initial stage of the trip, when the unit covers the first $52 \mathrm{~m}$, show that the AC strategy is more energy efficient and the difference in demand is about $10 \%$. It is worth noting, however, that the energy saving was achieved at the expense of a considerable extension of the cruise time, from about $38 \mathrm{~s}$ to about $50 \mathrm{~s}$. Such an extension of time is not always acceptable. 
The results of power demand measurements for a greater range of accelerations would be worth considering. New tooling at the model test laboratory is now being created to allow more extensive research.

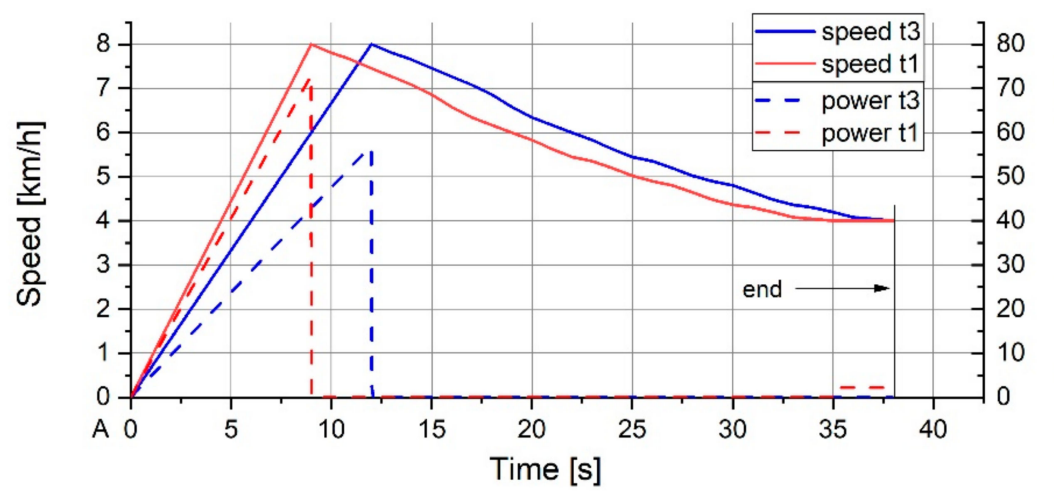

Figure 9. Profile of speed and power demand in the first stage of the cruise using the AG strategy at two different accelerations, $\mathrm{t} 1$ and $\mathrm{t} 3$, when the ferry covers $52 \mathrm{~m}$.

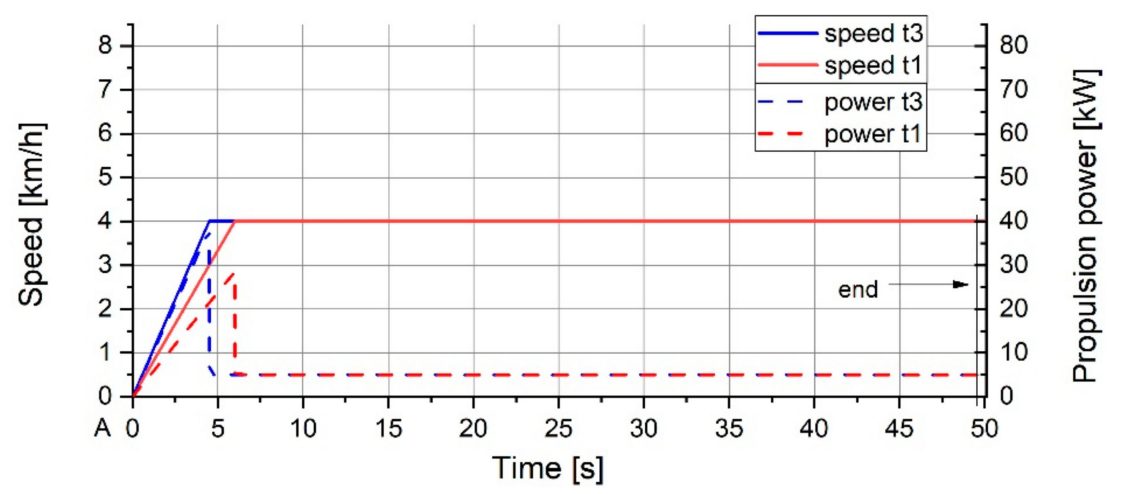

Figure 10. Profile of speed and power demand in the first stage of the cruise using the AC strategy when the ferry covers $52 \mathrm{~m}$.

Table 1. Comparison of the actual energy demand of a ferry moving in accordance with the adopted $\mathrm{ACB}$ and AGB strategies for one hour, making ten return trips.

\begin{tabular}{|c|c|c|c|c|c|}
\hline \multicolumn{3}{|c|}{ ACB Vmax $=6 \mathrm{~km} / \mathrm{h}$ (Figure $7 \mathrm{a}$ ) } & \multicolumn{3}{|c|}{ AGB Vmax $=8 \mathrm{~km} / \mathrm{h}$ (Figure $8 \mathrm{a}$ ) } \\
\hline Manoeuvre & Time [s] & Energy Consumed [kWs] & Manoeuvre & Time $[s]$ & Energy Consumed [kWs] \\
\hline Accelerating & 7.5 & 178.5 & Accelerating & 10 & 333.3 \\
\hline Constant speed & 42.5 & 141.6 & Gliding & 16 & 0 \\
\hline Gliding & 15 & - & Constant speed & 30 & 112.5 \\
\hline Braking & 20 & 133.3 & Gliding & 9 & 0 \\
\hline- & - & - & Braking & 20 & 133.3 \\
\hline \multicolumn{2}{|l|}{ Total: } & 453.4 & \multicolumn{2}{|l|}{ Total: } & 579.1 \\
\hline \multicolumn{2}{|c|}{10 Return Trips-1 h } & $2.51 \mathrm{kWh}$ & \multicolumn{2}{|c|}{10 Return Trips-1 h } & $3.21 \mathrm{kWh}$ \\
\hline \multicolumn{3}{|c|}{ ACB Vmax $=8$ km/h (Figure $7 \mathrm{~b}$ ) } & \multicolumn{3}{|c|}{ AGB Vmax = 10km/h (Figure 8a) } \\
\hline Manoeuvre & Time [s] & Energy Consumed [kWs] & Manoeuvre & Time $[s]$ & Energy Consumed [kWs] \\
\hline Accelerating & 10 & 333.3 & Accelerating & 12.5 & 496 \\
\hline Constant Speed & 30 & 233.26 & Gliding & 32.5 & 0 \\
\hline Gliding & 25 & - & Constant Speed & 20 & 45 \\
\hline Braking & 20 & 133.3 & Braking & 20 & 133.3 \\
\hline \multicolumn{2}{|l|}{ Total: } & 699.86 & \multicolumn{2}{|l|}{ Total: } & 674.3 \\
\hline \multicolumn{2}{|c|}{10 Return Trips-1 h } & $3.88 \mathrm{kWh}$ & \multicolumn{2}{|c|}{10 Return Trips-1 h } & $3.74 \mathrm{kWh}$ \\
\hline
\end{tabular}


Table 2. Power demand and trip time for a distance of $52 \mathrm{~m}$.

\begin{tabular}{|c|c|c|c|c|c|}
\hline \multicolumn{3}{|c|}{ AG, Course t1 } & \multicolumn{3}{|c|}{ AC, Course $t 1$} \\
\hline Manoeuvre & Time [s] & Energy Consumed [kWs] & Manoeuvre & Time [s] & Energy Consumed [kWs] \\
\hline Accelerating & - & 342.8 & Accelerating & 6 & 85 \\
\hline Gliding & 0 & 0 & Constant Speed & 44 & 220 \\
\hline- & Total: & 342.8 & - & Total: & 305 \\
\hline \multicolumn{3}{|c|}{ AG, Course t 2} & \multicolumn{3}{|c|}{ AC, Course t 2} \\
\hline Manoeuvre & Time [s] & Energy Consumed [kWs] & Manoeuvre & Time [s] & Energy Consumed [kWs] \\
\hline Accelerating & - & 333.3 & Accelerating & 5 & 84 \\
\hline Gliding & 0 & 0 & Constant Speed & 45 & 220 \\
\hline Constant Speed & 2 & 10 & - & - & - \\
\hline- & Total: & 343.3 & - & Total: & 304 \\
\hline \multicolumn{3}{|c|}{ AG, Course t 3} & \multicolumn{3}{|c|}{ AC, Course $t 3$} \\
\hline Manoeuvre & Time $[s]$ & Energy Consumed [kWs] & Manoeuvre & Time [s] & Energy Consumed [kWs] \\
\hline Accelerating & - & 328.5 & Accelerating & 4.5 & 85 \\
\hline Gliding & - & 0 & Constant Speed & 45.5 & 222.5 \\
\hline Constant Speed & 3 & 15 & - & - & - \\
\hline- & Total: & 343.5 & - & Total: & 307.5 \\
\hline
\end{tabular}

\section{Conclusions}

The test results show that slow acceleration, navigation at low constant speed, and finally braking preceded by a short glide is the most energy efficient method of navigation. The research shows that the cruise time is a critical parameter. If we want to save time, energy consumption increases. Therefore, according to the authors, when calculating an energy balance of a similar unit, one should know the answer to the question of how long a single trip should last.

The ferry in question covers a route of about $100 \mathrm{~m}$ across the river, which is about $50 \mathrm{~m}$ wide. Moving the mooring points so that the unit runs "straight ahead" would allow for a significant reduction in the amount of energy consumed. During such a cruise, when the ferry is moored by the bow and stern, it is usually possible to install a wide ramp on the ship instead of a gangway. This makes it possible to significantly accelerate the time of passengers' departure from and entry onto the ship. Thanks to such a solution, it would be possible to extend the trip time without changing the frequency of running, which would make it possible to reduce the energy consumption.

In Table 1 it is noticeable that in the same route power demand is different. By planning the entire route, it is worth thinking about how to move. Based on the comparison above, it has been proven that covering the same route at the same time can cause large differences in energy consumption. Preparing a movement strategy for a specific unit helps reduce that energy.

It is worth noting that photovoltaic panels with a capacity of about $2 \mathrm{kWp}$ are quite a significant source of energy in this system. In the high season, during the summer months, it can be expected that energy production will amount to 5-10 $\mathrm{kWh}$, which will have an impact on improving the energy balance, reducing operating costs, and increasing the level of energy security.

The development of an energy-efficient cruising method for a vessel operating on a short route is of key importance for the energy consumption of the transport process. Reducing the number of battery packs from the original set of 44 modules to 18 units represents significant savings at the stage of ship construction. The reduction of energy consumption, and therefore the reduction of the number of batteries, has an impact on the natural environment. Batteries are charged from the power grid, so reducing energy consumption is important, but it seems that more crucial is the fact that a smaller number of batteries means a lower environmental burden at the stages of extracting raw materials, production, and, finally, disposal of batteries.

It is worth noting that the hybrid watercraft is significantly different from the land vehicle. Vehicle designers benefit from many years of experience and vehicles are produced in series, so the 
number of experiments, including practical ones, is considerable. In the case of a vessel, usually one object is created. In exceptional cases, a short series of, usually, several vessels are made. We cannot use energy recovery during vessel braking, which is typical in the automotive industry. A vehicle goes up a hill and then descends from the top. In the case of a ship, the mass of the object is usually high, so the forces of inertia are significant and must be overcome during manoeuvring. Moreover, despite the low speed of the vessel, the resistance of the air and the impact of wind pressure should be taken into account, especially when the ship runs on an unprotected water area. In the case of shuttle vessels, with the duration of a cruise roughly corresponding to the stop time necessary for passengers to board, supercapacitors, loaded each time before the cruise, seem to be an attractive solution. Lithium batteries would only fulfil the function of a protective power source. The process of accelerating and braking the vessel has a high energy consumption. It is worth considering energy recovery through a system installed on the mooring site. The energy stored after the braking process could be used in the first stage of accelerating the unit.

Author Contributions: Conceptualization, W.L. and M.K.; methodology, W.L., M.K.; software, W.L.; validation, M.K., W.L.; resources, M.K., W.L.; writing-original draft preparation, M.K.; writing-review and editing, W.L.; visualization, W.L.; supervision, W.L.; funding acquisition, W.L.

Funding: This research received no external funding.

Conflicts of Interest: The authors declare no conflict of interest.

\section{References}

1. Mccoy, B.T.J. Electric Ships: Past, Present, and Future. IEEE Electrfication Mag. 2015, 3, 4-11. [CrossRef]

2. Ampere Electric-Powered Ferry-Ship Technology 2019. Available online: https://www.ship-technology. $\mathrm{com} /$ projects/norled-zerocat-electric-powered-ferry/ (accessed on 11 September 2019).

3. Jeong, B.; Oguz, E.; Wang, H.; Zhou, P. Multi-criteria decision-making for marine propulsion: Hybrid, diesel electric and diesel mechanical systems from cost-environment-risk perspectives. Appl. Energy 2018, 230, 1065-1081. [CrossRef]

4. Tsitsilonis, K.-M.; Theotokatos, G. A novel systematic methodology for engines energy management. J. Clean. Prod. 2018, 204, 212-236. [CrossRef]

5. Yuan, Y.; Wang, J.; Yan, X.; Li, Q.; Long, T. A design and experimental investigation of a larde scale solar energy/diesel generator powered hybrid ship. Energy 2018, 165, 965-978. [CrossRef]

6. Stateczny, A.; Burdziakowski, P. Universal autonomous control and management system for multipurpose unmanned surface vessel. Polish Marit. Res. 2019, 26, 30-39. [CrossRef]

7. Ahmed, A.S.; Sadek, S.I. Techno-economic approach to solar energy systems onboard marine vehicles. Polish Marit. Res. 2016, 23, 64-71.

8. Ammar, N.R.; Seddiek, I.S. Thermo-economic analysis and environmental aspects of absorption refrigeration unit operation onboard marine vehicles: Ro-pax vessel case study. Polish Marit. Res. 2018, 25, 94-103. [CrossRef]

9. Kunicka, M.; Litwin, W. Energy efficient small inlad passenger shuttle ferry with hybrcid propulsion—concept design, calculations and model tests. Polish Marit. Res. 2019, 26, 85-92. [CrossRef]

10. Welaya, Y.M.A.; el Gohary, M.M.; Ammar, R.N. A comparison between fuel cells and other alternatives for marine electric power generation. Int. J. Nav. Archit. Ocean Eng. 2011, 3, 141-149. [CrossRef]

11. Kalikatzarakis, M.; Geertsma, R.D.; Boonen, E.J.; Visser, K.; Negenborn, R.R. Ship energy management for hybrid propulsion and power supply with shore charging. Control Eng. Pract. 2018, 76, 133-154. [CrossRef]

12. Rodrigues, T.A.; Neves, G.S.; Gouveia, L.C.S.; Abi-Ramia, M.A., Jr.; Fortes, M.Z.; Gomes, S., Jr. Impact of electric propulsion on the electric power quality of vessels. Electric Power Syst. Res. 2018, 155, 350-362. [CrossRef]

13. Fotis, D.K.; Anvari-Moghaddam, A.; Guerrero, J.M. A cost-effective and emission-aware power management system for ship with integrated full electric propulsion. Electric Power Syst. Res. 2017, 150, 63-75.

14. Ji, Q.; Liu, G. A starting method of ship electric propulsion permanent magnet synchronous motor. Procedia Eng. 2011, 15, 655-659. [CrossRef] 
15. Zahedi, B.; Lars, E.; Kristine, N.; Ludvigsen, B. Optimized efficiency of all-electric ships by dc hybrid power systems. J. Power Sources 2014, 255, 341-354. [CrossRef]

16. George, M.; Antonios, M.; Dimitrios, I.D.; Tomas, T.; Dimitris, L. On battery state estimation algorithms for electric ship applications. Electric Power Syst. Res. 2017, 151, 115-124.

17. Ameen, M.B.; Alexander, B.P.; Stephen, R.T.; Philip, A.W. Development of a multi-scheme energy management strategy for a hybrid fuel cell driven passenger ship. Int. J. Hydrog. Energy 2017, 42, 623-635.

18. Balsamo, F.; Capasso, C.; Miccione, G.; Veneri, O. Hybrid storage system control strategy for all-electric powered ships. Energy Procedia 2017, 126, 1083-1090. [CrossRef]

19. Geertsma, R.D.; Negenborn, R.R.; Visser, K.; Hopman, J.J. Desing and control of hybrid power and propulsion systems for smart ships: A review of developments. Appl. Energy 2017, 194, 30-54. [CrossRef]

20. Litwin, W.; Lesniewski, W.; Piatek, D.; Niklas, K. Experimental research on the energy efficiency of a parallel hybrid drive for an inland ship. Energies 2019, 12, 1675. [CrossRef]

21. Litwin, W.; Leśniewski, W.; Kowalski, J. Energy efficient and environmentally friendly hybrid conversion of inland passenger vessel. Polish Marit. Res. 2017, 24, 77-84. [CrossRef]

22. Litwin, W.; Leśniewski, W.; Kowalski, J. Multi-source-supplied parallel hybrid propulsion of the inland passenger ship STAH Research work on energy efficiency of a hybrid propulsion system operating in the electric motor drive mode. Polish Marit. Res. 2013, 20, 20-27.

23. Stokoe, E.A. Reed's Ship Construction for Marine Students; Bloomsbury Publishing: London, UK, 2013 ; Volume 5. Available online: https://app.knovel.com/hotlink/toc/id:kpINFNB0U1/reeds-ship-construction/reeds-shipconstruction (accessed on 11 September 2019).

24. Rawson, K.J.; Tupper, E.C. Basic Ship Theory, 5th ed.; Elsevier: Amsterdam, The Netherlands, 2001. Available online: https:/app.knovel.com/hotlink/toc/id:kpBSTE0006/basic-ship-theory-5th/basic-ship-theory5th (accessed on 11 September 2019).

25. Bronz, M.; Moschetta, J.-M.; Hattenberger, G. Multi-Point Optimisation of a PropulsionSet as Applied to a Multi-Tasking MAV. IMAV. 2012. Available online: https://hal-enac.archives-ouvertes.fr/hal-00993461/ document (accessed on 11 September 2019).

26. Anderson, P. A Comparative Study of Conventional and Tip-Fin Propeller Performance, National Research Council. Available online: https://www.nap.edu/read/5870/chapter/64 (accessed on 11 September 2019).

27. Molland, A.F.; Turnock, S.R.; Dominic, A.; Hudson, D.A. Ship Resistance and Propulsion: Practical Estimation of Ship Propulsive Power; Cambridge University Press: Cambridge, UK, 2011.

28. Holtrop, J. Statistical Data for The Extrapolation of Model Performance Tests. In International Shipbuilding Progress; IOS Press: Delft, The Netherlands, 1978; Volume 25.

29. Holtrop, J. A Statistical Re-Analysis of Resistance and Propulsion Data. Available online: https://www. scribd.com/document/210986199/Holtrop-A-Statistical-Re-Analysis-of-Resistance-and-Propulsion-Data (accessed on 11 September 2019).

30. ITTC-Recommended Procedures, Fresh Water and Seawater Properties 7.5-02-01-03. 2011. Available online: http://ittc.info/media/1215/75-02-01-03.pdf (accessed on 11 September 2019).

31. ITTC Recommended Procedure, Resistance Test 7.5-02-02-01. 2011. Available online: http://ittc.info/media/ 1217/75-02-02-01.pdf (accessed on 11 September 2019).

32. Harilaos, N.; Psaraftis, C.; Kontovas, A. Ship speed optimization: Concepts, models and combined speed-routing scenarios. Transp. Res. Part C 2014, 44, 52-69.

33. Jafarzadeh, S.; Schjolberg, I. Operational profiles of ships in Norwegian waters: An activity-based approach to assess the benefits of hybrid and electric propulsion. Transp. Res. Part D Transp. Environ. 2018, 65, 500-523. [CrossRef]

34. Derollepot, R.; Vinot, E. Sizing of a combined series-parallel hybrid architecture of river ship application using genetic algorithm and optimal energy management. Math. Comput. Simul. 2019, 158, 248-263. [CrossRef]

(C) 2019 by the authors. Licensee MDPI, Basel, Switzerland. This article is an open access article distributed under the terms and conditions of the Creative Commons Attribution (CC BY) license (http://creativecommons.org/licenses/by/4.0/). 